DOI: $10.1515 / \mathrm{rpp}-2016-0022$

Master of Science, MICHAL HNATIUK

Przemyśl Center of Vocational and Continuing Training, Poland Address: 127/42 Grunwaldzka St., Przemyśl, 37-700, Poland

E-mail: Hnatiuk@op.pl

\title{
QUALITATIVE AND QUANTITATIVE CHANGES OF UPPER SECONDARY EDUCATION IN POLAND
}

\begin{abstract}
The article presents the Polish educational system, its constituent part - upper secondary education, in particular. Describing the qualitative changes in the upper secondary schools (secondary schools of the second extent) the author singles out one significant document that has changed the direction of education, created the conditions for change of the educational management system and introduced the economic rules in educational activities. It also shows the structure of upper secondary education, which was formed in the final stage of the educational reforms. The peculiarities of the qualitative changes have been indicated. The previous system of assessing students' knowledge was preserved; however, an external evaluation of the students' achievements was introduced. The introduction of the external exams and assessments has enabled a fair comparison of the level of skills that the student has achieved to the skills that are required by the syllabus. Therefore, it is believed that the changes introduced have become one of the pillars of the reform of the educational system in Poland. The quantitative changes have been introduced along with the qualitative ones. Quantitative changes were compared in the period 2000-2015 and juxtaposed with the year 1990. On the basis of the gathered statistical data a trend was set (downward or upward) in Polish upper secondary education.

Key words: the 1991 Law of the Educational System, upper secondary education, structure of upper secondary education, the scale of the evaluation of knowledge and skills, external assessment of the students achievements, quantitative changes in upper secondary education, increasing or decreasing trend in education.
\end{abstract}

\section{INTRODUCTION}

In Poland at the beginning of the transformation the correlation between the changing of the political establishment and the economic and the national system of education could already be seen. The significant document that changed the direction of the development of Polish education was the Law of the Educational System passed on September 7 in 1991. It was a significant readjustment of the educational system in Poland. It created the conditions for a gradual transition from centralisation to decentralisation of the management of education, from the monopolisation of education to its demonopolisation and also for the introduction of economic rules into educational activities (Nyczkało, Szlosek, 2008).

The 1991 Law of the Educational System was like a double-edged sword. On the one hand, it reformed the educational system, introduced innovative changes in order to serve the public better but, on the other hand, it encouraged the management of schools to use the saving policy which could sometimes be met with a negative response from the society.

In the 1990s to avoid generating educational debt there were limits for all teaching classes to a few hours in the framework learning plans, school activities were restricted and 
teachers' salaries were cut down by about $10-15 \%$ and more in comparison to the national average (Śliwerski, 2009).

The decisions taken by the politicians did not disrupt the social transformation and socialisation of the educational system. Mostly, they served to continue the previously initiated changes but in a slightly altered form. For example, in support of the Law of the Educational System the governing political party introduced a new reforming project. Among others there was the project "Basis of Syllabus in Compulsory Educational Subjects" that contains the tasks, the content of school education and the desired competencies. It is worth noting that some scientific circles often had reservations about the project (Sławiński, 1997).

\section{THE AIM OF THE STUDY}

The purpose of the research was to collect empirical data, including statistics that describe the quantitative and qualitative changes in secondary schools of second extent. On the basis of the collected data, trends were determined (downward or upward) in upper secondary education. The investigation period covered the educational changes during the period of 1990-2015.

\section{THEORETICAL FRAMEWORK AND RESEARCH METHODS}

In terms of social transformation the reorganisation of education of the youth has taken on particular importance. Therefore, both subject matter, teaching methodology and educational issues including vocational training were described in the works of W. Furmanek, Cz. Kupisiewicz, B. Niemierko, T. Nowacki, N. G. Nyczkało, F. Szlosek, B. Śliwerski and other scientists. While describing the educational transformation in the scientific works not only qualitative changes but also the quantitative ones were analysed.

On the basis of the methodology of the research the article was compiled. In the research such methods were applied as monograph and statistical methods. Presenting upper secondary education the comparative method was also used. It gave the opportunity to compare the emerging trends in Polish secondary schools of the second extent within a period of twenty-five years.

\section{RESULTS}

In Poland as in many other European countries the first level of the educational system is pre-primary education. The next stage of the implementation of compulsory education involves primary education. Educating pupils in primary school lasts six years. In the last year of education the pupils take a compulsory test (known as an exam), which checks their skills obtained during education and compared with the skills required by the core curriculum. After finishing primary (elementary) school, all pupils (without selection) are accepted to a junior high school (grammar school). The compulsory education in junior high school lasts three years. Exam results and the final assessment of students' achievements in each subject are recorded on the school certificate. During the recruitment process to upper secondary school the results of the exam are converted into points, which play a decisive role on whether or not a student is accepted by chosen secondary school (Fundacja Rozwoju Systemu Edukacji, Eurydice, 2014).

While presenting the upper secondary schools it is worth noting that the whole structure of secondary education of the second extent has remained very extensive. In such a complex structure of schools the attention is primarily paid to educational institutions, which are the most common.

In the process of educational transformation some of the schools were closed down and those that remained still survive to this day. After the final reorganisation carried out in 2014 and 2015 the secondary schools of the second extent were included in the following educational establishments: 
- high schools;

- technical colleges;

- vocational schools;

- colleges of further education.

At the level of upper secondary schools there is operative subject teaching. The Ministry of Education determines the core curricula for each type of school and for all subjects. The subjects are taught at a basic or advanced level. The students themselves choose between two and four subjects that they study at an advanced level for the final examination including at least one of the following: History, Geography, Biology, Chemistry or Physics. Teachers can choose the textbooks from a list approved by the Ministry of Education, decide the teaching and assessment methods and introduce innovative teaching methods. The right to education also enables them to develop their own curricula based on the core curricula (Fundacja Rozwoju Systemu Edukacji, Eurydice, 2014).

In primary schools (starting with the fourth grade), junior high schools and secondary schools of the second extent the assessment of students knowledge and skills in most cases is done on the basis of their answers orally or in writing. The evaluation of educational activities is put in degrees according to the following scale:

$$
\begin{aligned}
& \text { - excellent }-6 ; \\
& \text { - very good }-5 ; \\
& \text { - good }-4 ; \\
& \text { - sufficient }-3 \text {; } \\
& \text { - permitting }-2 \text {; } \\
& \text { - insufficient }-1 \text {. }
\end{aligned}
$$

Midterm and final assessment is also done according to a similar scale. Depending on the result of the final assessment, a student is promoted to the next year. The prerequisite for the promotion is getting a grade higher than the insufficient one from all educational subjects. If a student obtains one or two insufficient grades, they can take an exam in order to get the promotion. If the student does not pass at least one of the exams, then he is required to repeat the year. At this point, it is worth noting that the Pedagogical Council of schools may vote by majority in favour of a conditional promotion for the student to go onto the next year with one insufficient grade.

Education at secondary schools of the second extent lasts three years and in the case of technical colleges - four. At the end of the last year of education in high schools school leaving exams are conducted. In vocational schools the examinations confirming qualifications in the profession take place. In technical colleges both exams - school leaving exams and exams confirming qualifications in the profession take place. The number of exams depends on the number of qualifications that are singled out in the profession (one, two or three) confirming given qualifications. It is worth pointing out that each exam consists of two parts: written and practical ones. Each of the fore-mentioned exams, both school leaving and the ones confirming qualifications are external. They are conducted by a District Examination Board. There are eight of them in Poland and they are supervised by the Central Examination Board (The Sejm of Republic of Poland, 1991).

The results obtained in the external exams and tests are final. If the student has passed the exam, they are not allowed to improve the result in the same school year. A student can get permission to improve the result of the exam in the following session of school leaving examinations. However, if the student did not take the examination at all or did not pass it, they are entitled to take the exam at another time or in a subsequent session of the examination. 
It is worth noting that in scientific publications describing the Reform of the System of National Education in Poland it was emphasised that the introduction of external examinations and tests on the following levels of education was one of the pillars of the Reform of the Educational System in Poland. The researchers have also indicated that despite the objections and threats the introduction of an external assessment of student achievements seems to be a relevant solution, clearly influencing the improvement of the quality of education, although it has raised enormous organisational, factual, methodological and financial problems (Nyczkało, Szlosek, 2008).

Thus, the fore-mentioned changes in education such as decentralisation of the educational system, the introduction of economic rules to educational activities, structural reorganisation of secondary education schools and the introduction of external assessment of students achievements are considered as significant changes to the quality of the Polish Educational System including the upper secondary education.

Comparing each stage of education it is easy to observe that during the 25 -year period of educational transformation the biggest changes have taken place at the upper secondary school level. Some of these changes are expressed in numerical values and they are presented in the tables below. Table 1 contains the data collected about high schools, technical colleges, vocational schools and the number of students attending these schools. In table 2 there are statistical data about colleges of further education.

Table 1

Upper secondary education in Poland in 1990 and during the period of 2000-2015

\begin{tabular}{|c|c|c|c|c|c|c|}
\hline Years & $\begin{array}{c}\text { High } \\
\text { schools }\end{array}$ & $\begin{array}{c}\text { Students } \\
\text { in thousands }\end{array}$ & $\begin{array}{c}\text { Technical } \\
\text { college }\end{array}$ & $\begin{array}{c}\text { Students } \\
\text { in thousands }\end{array}$ & $\begin{array}{c}\text { Vocational } \\
\text { schools }\end{array}$ & $\begin{array}{c}\text { Students } \\
\text { in thousands }\end{array}$ \\
\hline $1990 / 91$ & 1100 & 445,0 & 3607 & 636,6 & 2995 & 814,5 \\
\hline $2000 / 01$ & 2292 & 924,1 & 5909 & 985,9 & 2372 & 542,0 \\
\hline $2001 / 02$ & 2296 & 716,8 & 6009 & 787,7 & 2209 & 348,5 \\
\hline $2002 / 03$ & 4089 & 839,7 & 4854 & 721,0 & 2227 & 265,1 \\
\hline $2003 / 04$ & 4238 & 922,0 & 4526 & 659,8 & 1919 & 204,0 \\
\hline $2004 / 05$ & 4208 & 982,7 & 3750 & 557,9 & 1845 & 239,3 \\
\hline $2005 / 06$ & 4102 & 940,8 & 2902 & 528,4 & 1778 & 232,5 \\
\hline $2006 / 07$ & 3959 & 892,9 & 2473 & 535,0 & 1760 & 229,2 \\
\hline $2007 / 08$ & 3655 & 825,8 & 2447 & 549,4 & 1769 & 235,6 \\
\hline $2008 / 09$ & 3390 & 760,5 & 2372 & 555,2 & 1784 & 239,1 \\
\hline $2009 / 10$ & 3075 & 705,4 & 2243 & 555,8 & 1785 & 235,7 \\
\hline $2010 / 11$ & 2885 & 668,7 & 2204 & 548,7 & 1763 & 224,9 \\
\hline $2011 / 12$ & 2795 & 635,1 & 2155 & 532,0 & 1754 & 210,9 \\
\hline $2012 / 13$ & 2718 & 594,3 & 2082 & 522,5 & 1757 & 197,2 \\
\hline $2013 / 14$ & 2522 & 553,1 & 2048 & 515,9 & 1708 & 184,5 \\
\hline $2014 / 15$ & 2286 & 523,8 & 1957 & 510,1 & 1712 & 190,0 \\
\hline
\end{tabular}

Source: developed by the author on the basis of a study of the Chief Statistical Bureau (CSB) data. Statistical Yearbook 2000-2015 by http://stat.gov.pl/wyszukiwarka/ szukaj.html 
Colleges of Further Education in Poland in 1990 and during the period of 2000-2015

\begin{tabular}{|c|c|c|c|c|c|c|c|c|c|c|c|c|c|c|c|c|}
\hline Years & $\begin{array}{l}\bar{\sigma} \\
\text { مे }\end{array}$ & $\begin{array}{l}\text { o } \\
\text { ᄋ } \\
\text { ¿े }\end{array}$ & $\begin{array}{l}\text { ô } \\
\text { ळे } \\
\text { ते }\end{array}$ & $\begin{array}{l}\text { ô } \\
\text { ते } \\
\text { ֻे }\end{array}$ & 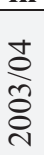 & 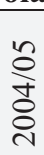 & 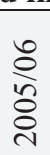 & 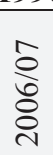 & $\frac{\infty}{\stackrel{\infty}{人}}$ & 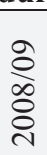 & $\begin{array}{l}\stackrel{0}{a} \\
\text { ò } \\
\text { ㄱ }\end{array}$ & $\begin{array}{l}\bar{z} \\
\frac{1}{0} \\
\vdots\end{array}$ & 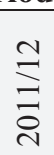 & $\frac{m}{\frac{m}{2}}$ & $\frac{ \pm}{\frac{\Xi}{2}}$ & $\frac{n}{\stackrel{n}{\partial}}$ \\
\hline $\begin{array}{l}\text { Colleges } \\
\text { of further } \\
\text { education }\end{array}$ & $\hat{\infty}$ & $\begin{array}{l}\hat{\sigma} \\
\stackrel{n}{2}\end{array}$ & 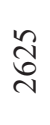 & $\begin{array}{l}\hat{i} \\
\infty \\
\sim\end{array}$ & $\frac{\bar{N}}{m}$ & $\frac{\mathscr{v}}{\stackrel{f}{m}}$ & $\frac{\bar{m}}{m}$ & $\underset{n}{\infty}$ & $\hat{m}$ & $\begin{array}{l}\text { bे } \\
\text { m}\end{array}$ & 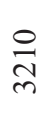 & $\vec{\nabla}$ & 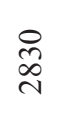 & $\stackrel{n}{\stackrel{n}{v}}$ & \begin{tabular}{l}
$\hat{\sigma}$ \\
\multirow{2}{*}{}
\end{tabular} & $\begin{array}{l}\widetilde{\infty} \\
\sim \\
\sim\end{array}$ \\
\hline $\begin{array}{c}\text { Students } \\
\text { in thousands }\end{array}$ & $\begin{array}{l}m \\
\infty \\
\infty\end{array}$ & ஓे & $\stackrel{0}{=}$ & $\begin{array}{l}n \\
\tilde{n}^{2} \\
\end{array}$ & in & กิ & $\frac{n}{m}$ & $\stackrel{\hat{N}}{n}$ & $\stackrel{0}{0}$ & $\overrightarrow{\text { f }}$ & $\begin{array}{l}\infty \\
\underset{\sim}{\infty} \\
\stackrel{+}{1}\end{array}$ & $\begin{array}{l}\infty \\
\infty \\
\curvearrowright\end{array}$ & $\begin{array}{l}0 \\
\text { @ } \\
m\end{array}$ & $\begin{array}{l}m \\
m \\
m\end{array}$ & $\frac{0}{2}$ & $\begin{array}{l}0 \\
\text { di } \\
\text { ते }\end{array}$ \\
\hline
\end{tabular}

Source: developed by the author on the basis of a study of the Chief Statistical Bureau (CSB) data. Statistical Yearbook 2000 - 2015 by http://stat.gov.pl/wyszukiwarkal szukaj.html

Analysing the changes in secondary schools it is worth noting that in the education of this type the quantitative changes of schools or students were a derivative of structural changes and demographic decline. The dynamics of changes in upper secondary schools have been shown in graphs 1 and 2 .

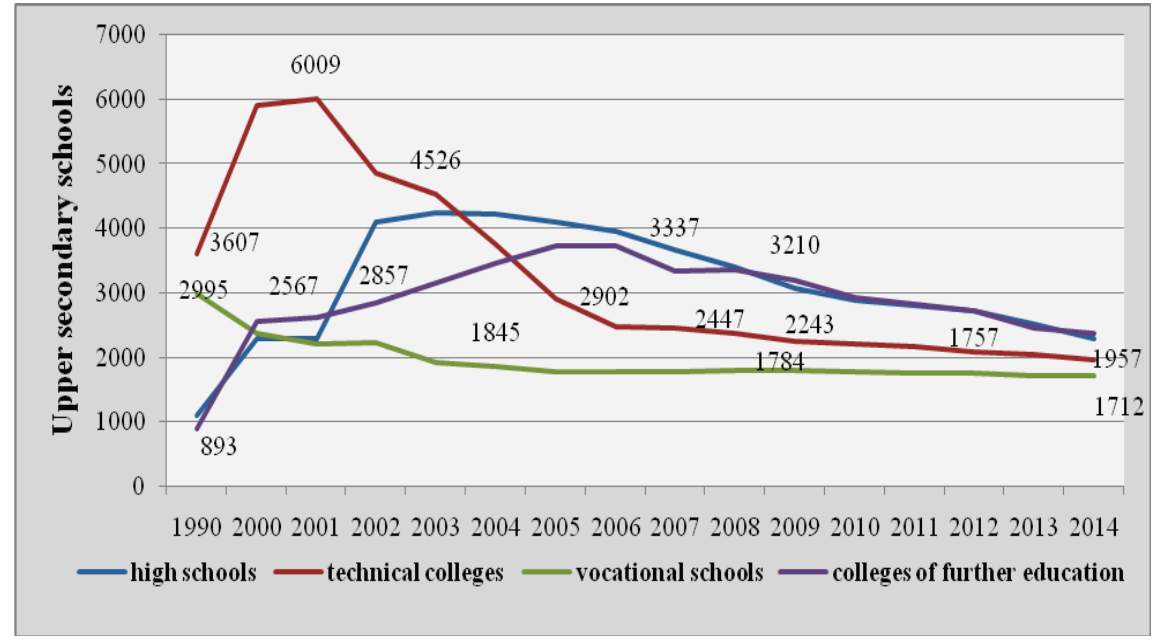

Graph 1. The number of upper secondary schools in Poland in 1990 and during the period of 2000-2015

Source: developed by the author on the basis of a study of the Chief Statistical Bureau (CSB) data. Statistical Yearbook 2000-2015 by http://stat.gov.pl/wyszukiwarka/ szukaj.html 


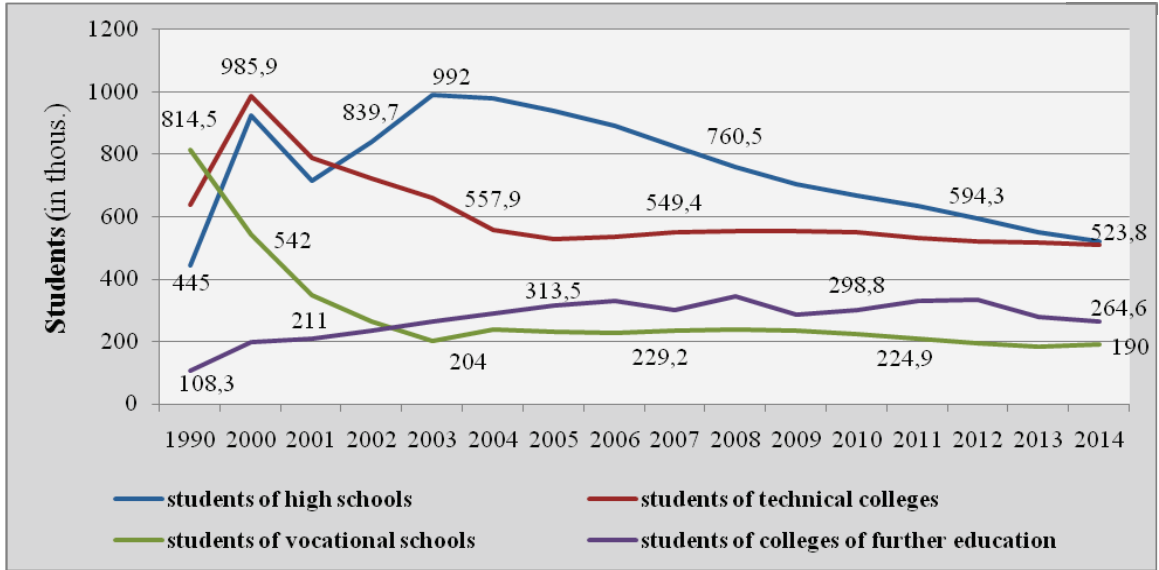

Graph 2. Number of students in upper secondary schools in Poland in 1990 and during the period of 2000-2015

Source: developed by the author on the basis of a study of the Chief Statistical Bureau (CSB) data. Statistical Yearbook 2000-2015 by http://stat.gov.pl/wyszukiwarkal szukaj.html

The impact of these factors (structural changes and demographic decline) on upper secondary education reflects the following statistics. In 1990, there were 1100 high schools in Poland, in 2001 - 2296, in 2005 - 4102, in 2010 - 2885 and in 2014 their number decreased to 2286. A similar situation could also be seen among technical colleges and colleges of further education. The largest number of technical colleges was noted in 2001 (6009), colleges of further education in 2006 (3738). However, by 2014 the situation had changed and the number of these educational institutions decreased respectively to 1957 and 2382 schools (Główny Urząd Statystyczny, 2016). In regards to the number of students in upper secondary education we can assert that their changing quota is a reflection of the changing status of education institutions with the only difference being that the number of students in colleges of further education has slightly increased compared to the year 1990.

Investigating changes in the Polish education system we mostly measured the numbers. However, the numbers in our study were not the most important. They served as a tool for obtaining information. More important for us was to describe the education system in Poland and show the direction of organisational and structural changes in upper secondary education. It is known that most of the changes could be easily expressed in numerical value. For this reason, numbers were collected, which to some extent constituted the statistical data and at the same time showed the direction to which the changes were going.

\section{CONCLUSIONS}

On the basis of the analysis of educational documents and the collected data we can conclude the following:

- since the end of the $20^{\text {th }}$ century institutional changes in Poland initiated the system qualitative changes such as the decentralisation of the educational management, the introduction of economic rules into the educational activities, structural reorganisation of secondary schools of the second extent as well as an introduction of an external assessment of the students' progress; 
- social transformation has also caused quantitative changes. Since 1990 the number of upper secondary schools (high schools, technical colleges and colleges of further education) has significantly increased. However, over time this increase has slowed down and changed direction, which has produced a downward trend. In the 25 -year period no increase in the number of vocational schools has been noted at all. Since 1990 at this level of education a slight but continuous downward trend has been observed;

- the number of students in upper secondary education altered depending on the structural changes introduced. To a certain extent it has been conditioned by a demographic factor. The collected statistical data clearly indicate that the quota of students in upper secondary education has been decreasing year by year outlining the downward trend at the same time. The opposite situation is in the colleges of further education. In these education institutions an upward trend is sometimes interrupted, however, in the investigated 25-year period the growth is still noticed.

The proposed research covers a wide range of issues for further comparative studies. New prospects of investigation of qualitative and quantitative changes deal with the expanding the study of the educational reforms conducting in other European countries. It opens up new prospects with a goal to increase the effectiveness of educational systems both by exchanging the experience and revealing the national and cultural peculiarities of different educational systems.

\section{REFERENCES}

1. Fundacja Rozwoju Systemu Edukacji. Eurydice [The Foundation of the Development of Educational System. Eurydice]. (2014). System edukacji w Polsce. [The System of Education in Poland]. Retrieved 08.11.2014 from : http://eurydice.org.pl/wp-content/uploads/ 2014/10/NSO_PL_2014_0.pdf.

2. Główny Urząd Statystyczny [The Chief Statistical Bureau]. (2016). Mały Rocznik Statystyczny 2000 - 2015 r. [Small Statistical Yearbook 2000-2015]. Retrieved 08.02.2015 from : http://stat.gov.pl/wyszukiwarka/szukaj.html.

3. Nyczkało, N. G., Szlosek, F. (2008). Ksztatcenie zawodowe w Polsce i Ukrainie na tle przemian [Vocational Training in Poland and Ukraine - in the Background of the Changes]. Warszawa - Radom : Wydawnictwo Naukowe Instytutu Technologii Eksploatacji Państwowego Instytutu Badawczego, 37 p. (in Polish).

4. Sejm RP [The Sejm of Republic of Poland]. (1991). Ustawa z dnia 7 września 1991 r. o systemie oświaty [The Law of the Educational System in 1991]. Retrieved 02.10.2013 from : http://isap.sejm.gov.pl/DetailsServlet?id=WDU19910950425.

5. Sławiński, S. (1997). Uwagi do projektu podstaw programowych [The Remarks about the Project of the Core Curricula]. Retrieved 29.05.2014 from : http://www.eid.edu.pl/ archiwum/1997,95/maj,129/uwagi_do_projektu_podstaw_programowych,588.html.

6. Śliwerski, B. (2009). Problemy współczesnej edukacji. Dekonstrukcja polityki oświatowej III RP [Problems of Modern Education. Deconstruction of the Educational Policy of the Third Republic of Poland]. Warszawa : Wydawnictwa Akademickie i Profesjonalne, 69 p. (in Polish). 